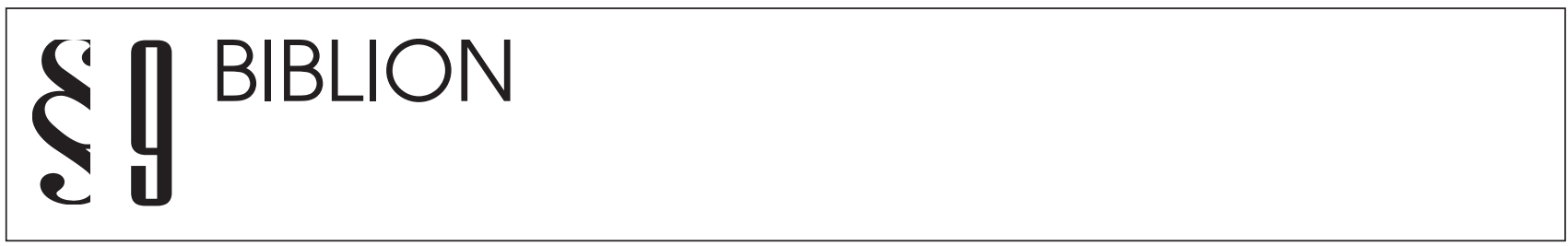

Дубовик О.Л.

\title{
ЭКОЛОГИЧЕСКИЕ ПРОТЕСТНЫЕ ДВИЖЕНИЯ В ГЕРМАНИИ. РЕЦЕНЗИЯ НА КНИГУ: НОВАЯ ВЛАСТЬ ГРАЖДАН / ОТВ. РЕД. С. МАРГ, Л. ГАЙГЕС, Ф. БУТЦЛАФФ, Ф. ВАЛЬТЕР. СЕРИЯ: ТОМ 1332. БОНН: ФЕДЕРАЛЬНЫЙ ЦЕНТР ПОЛИТИЧЕСКОГО ОБРАЗОВАНИЯ, 2013. - 341 c.
}

Аннотация: В рецеензии рассматриваются методология и результаты исследования протестного движения граждан в Германии. Экологически ориентированные акции и протесты в ФРГ иироко распространены и зачастую влияют на политические и правовые решения, принимаемые в этой стране. Охрана окружающей среды опирается на мощчню поддержку граждан. Протесты граждан ФРГ чаще всего направлень против реализации проектов крупномаситабного строительства, перекладки транспортных коммуникаций, возведения экологически опасных объектов и т.п. В книге описана история формирования протестного движения, исследованы ценностные ориентации активистов, т.е. организаторов и агитаторов, мотивы их деятельности, политические позиции. Указаньл формы протестов: инициативы, акции, демонстрации, митинги и др. Рассмотрень урбанистические протесты в Гамбурге, Штутгарте, Мюнхене, направленнье, соответственно, на защиту окружающей среды, включая культурное, архитектурное и историческое наследие. Особое внимание уделено антиатомному движению, имеющему в Германии широкую поддержку и добившемуся впечатляющих успехов - принятия «Тринадиатого закона об изменении Атомного закона», в соответствии с которым в августе 2011 г. были выведень из эксплуатации восемь атомных электростаниий, а до кониза 2022 г. должны быть остановлены пока еще девять действующих АЭС.

Ключевые слова: Активисты, граждане, антиатомное движение, экология, политика, протест, право, общественное мнение, соичильная группа, демократия.

Abstract: This review examines the methodology and results of the research on the protest movement of the German citizens. The environmental acts of protest in Germany are common and often influence the political and legal decisions made in this country. Protection of the environment is backed by a strong support from the citizens. The protests in Germany mostly aimed against various large-scale projects, laying transportation hubs, construction of environmentally unsafe objects, etc. The book describes the history of the forming of the protest movement, examines the value orientations of the activists, their motives and political positions. It reviews urban protests in Hamburg, Stuttgart and Munich, aimed at protecting the environment, including cultural, architectural and historical heritage. A special attention is given to the anti-nuclear movement that is widely supported throughout Germany and has reached great success.

Keywords: Public opinion, law, protest, politics, environment, anti-nuclear movement, citizens, activists, social group, democracy.

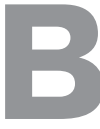

российской юридической, социологической, политологической, экологической литературе недостаточное внимание уделяется исследованиям причин возникновения протестов граждан, формам протестного движения, их целям, факторам, приводящим к прекращению акций, кругу участников и мотивации их действий. Частично эти вопросы из- учаются в рамках конфликтологии, частично - при исследовании деятельности общественных организаций и объединений, частично - юристами, занимающимися защитой прав и свобод человека и гражданина, и т.д. Но все же целостных представительных работ пока нет. В связи с этим интерес отечественных специалистов-правоведов, политологов, экологов, социологов 
DOI: $10.7256 / 1811-9018.2015 .4 .13329$

При цитировании этой статьи сноска на доі обязательна

\section{Право и политика 4 (184) 2015}

и многих других может несомненно вызвать фундаментальная разработка немецких ученых, результаты которой сконцентрированы в рецензируемой коллективной монографии.

Она посвящена исследованию протестного, в первую очередь, экологического движения в Федеративной Республике Германии. Ее авторы с самого начала подчеркивают, что если недавно (60-е - 70-е гг.) протесты были проявлением молодежных движений, то в немецком обществе XXI века ситуация значительно изменилась. Протесты граждан направлены против крупномасштабного строительства, прокладки новых дорожных трасс или линий электропередачи, экологического или социального негативного воздействия в результате развития городов, строительства АЭС и хранилищ радиоактивных отходов, реформ образования и т.п. В наши дни не только молодежь, но и люди, относящиеся к среднему классу, участвуют в действиях против такого рода проектов. Поэтому мотивы их деятельности, стратегии, которые они избирают формы протестов, их цели, достигнутые результаты, распространенность протестных движений, социальнодемографическая характеристика личности участников, несомненно представляет собой весьма интересный объект научного исследования.

Работа состоит из введения, девяти разделов и заключения. В конце каждого раздела содержится список литературы, позволяющий читателю не только расширить представление об анализируемом авторами вопросе, но и проследить степень новизны сделанных ими наблюдений и выводов, а также оценить методологию и методику проведенного масштабного исследования.

Во введении «Граждане в движении» (с. 7-11) $\Phi$. Вальтер указывает, что изучение протестов граждан было начато в Институте исследования демократии при Университете Геттингена и затем продолжено в рамках ряда проектов при поддержке Федерального центра политического образования. С методологической точки зрения важно, что изучение протестного движения осуществлялось как в экономически процветающих регионах Германии, так и в тех регионах, где показатели демографической и экономической ситуации характеризуются как более низкие. Исследователи обращали внимание на фактические действия людей, и, конечно, опрашивали многих участников протестов.

Первый раздел: «Как исследуются протесты? Исследовательский дизайн и методика» (с. 12-45). Его авторы (С.Клеха, С. Марг, Ф. Бутцлафф) подробно описывают методологические основы и объясняют причины выбора того или иного метода. Они подчер- кивают, что предметом исследования были протесты индивидов, их ценностные ориентации, ожидания и политические позиции, а не деятельность объединений и организаций, коллективных субъектов. В этих целях в качестве рабочего понятия при определении критериев отбора индивидуумов было избрано такое понятие как «активист». К числу «активистов» относятся мужчины и женщины, которые в организации, то есть в подготовке и проведении определенного протеста играли важную роль основных (центральных) организаторов или агитаторов. В то же время, чтобы не оставить без внимания роль и мотивы тех участников протестов, которые относятся к «тихим» стратегам или, напротив, радикалам, данный критерий был дополнен понятием «уровень активности».

Основными методами исследования были избраны следующие: нарративные и фокусированные интервью, групповые дискуссии (проведенные в семи группах), включенное наблюдение, аналитическое изучение документов, в том числе материалов, опубликованных в средствах массовой информации.

Во втором разделе «Мы больше не позволим все с нами делать»: Гражданские протесты в и о публичном пространстве, инфраструктуре и развитии городов» (c. 46-91). Анализнруемые в нем протесты носят экологически ориентированный характер, поскольку касаются пространственного и ландшафтного планирования, влияния строительства и реконструкции зданий и сооружений на сохранение среды обитания человека, включая культурное, архитектурное, историческое наследие. Авторы этого раздела Ф. Бутцлафф, К. Хёфт, Ю. Копп описывают историю и результаты трех известных протестов. Первый проходил в Гамбурге начиная с 2008 г. под лозунгом «Право и город» и охватывал 56 инициатив. Он является ярким примером урбанистического протестного движения, направленного на экологически дружественное планирование городской территории, сохранение зеленых зон и т.п. и против больших строительных проектов, например, большого Музыкального театра. Второй протест был вызван так называемым проектом «Штутгарт 21» о реконструкции памятника архитектуры - Штутгартского вокзала и наносимого при этом ущерба замковому парку и повлек значительные политические последствия. В частности, при выборах в Ландтаг Баден-Вюртемберга в марте 2011 г. Как никакой другой он широко отражался в средствах массовой информации на протяжении двух лет. Де юре было принято решение о продолжении строительства, но конфликт продолжается в более мягких формах. Отличительными чертами данного протеста, 
как отмечают авторы, является то, что его участники - это образованные, информированные, опирающиеся на прочную базы и специализированные экспертные познания люди. В первую очередь для них значимо признание социальных ценностей и то, что они как граждане ощущали себя затронутыми. Третий протест был вызван проектом расширения Мюнхенского аэропорта (строительство новой взлетно-посадочной полосы). Значительная роль в нем принадлежала евангелической и католической церквям, поддерживавшим организацию Форума, проведение шествий, осуществление иных акций.

В третьем разделе «Если хотят для природы что-то сделать, то не устанавливают там мачты»: Гражданские протесты против проектов строительства, связанных с новой энергетической политикой» (с. 92-136), его авторы (С. Марг, К. Херманн, В. Хамбауэр, А.Б. Беке) анализируют протесты граждан против строительства ветровых парков, которые нарушают типичный немецкий ландшафт, линий электропередачи, иных объектов энергетики, изъятия земель и др. В целом это типичные протесты защитников окружающей среды, борющихся с самыми разнообразными проектами, реализация которых влечет негативные последствия, нарушающие жизненное пространство, среду обитания человека, приносящих вред сохранению биоразнообразия. Широко известны протесты против строительства плотин и дамб, вырубки лесов, прокладки транспортных путей и т.п. Такого рода протесты известны давно, но, как подчеркивают авторы, новым является темп, скорость их организации и проведения. При этом среди участников протестов активны не только представители населения, проживающего в местности, где устанавливаются ветровые мачты, но и специалисты-экологи, которые в последнее время как в общей печати, так и в специализированных изданиях все чаще обращают внимание на минусы использования второй энергии и возникающие при этом риски. Это действительно очень сложный вопрос: ведь получение энергии всегда связано с негативным воздействием на окружающую среду. В любом случае приходится осуществлять выбор между источниками получения энергии. Авторы данного раздела не рассматривают научную и экономическую обоснованность использования энергии ветра, а исследуют реакцию граждан и их аргументацию, их мотивы.

Наиболее ярким в плане характеристики экологических протестов является пятый раздел «Без организации это неосуществимо»: Антиатомное движение» (с. 159-177). В нем содержится анализ истории формирования и развития антиатомных протестов в
Германии, его форм, круга участников, поразительных достигнутых ими результатов. Его авторы - Л. Гайгес, Т. Нееф, П. Ван Дийк, Ф. Хартманн, в самом начале отмечают: «Достиг ли протест своей цели? В июне 2011 г. немецкий Бундестаг принял «Тринадцатый закон об изменении Атомного закона» ${ }^{1}$ и вывел из эксплуатации в августе того же года восемь атомных реакторов. До конца 2022 г. должны быть остановлены еще девять. Немецкое правительство практически в течение одной ночи переменило свое мнение вскоре после катастрофы на атомной электростанции в Японии, под влиянием предстоящих выборов в ландтаги и 250000 людей на улицах, которые требовали немедленного отказа от использования атомной энергии. Германский канцлер Ангела Меркель сказала, что Фукусима изменила ее отношение к атомной энергии. Конец атомных станций в Германии наступил внезапно и в течение нескольких недель были обсуждены и приняты решения, которых противники использования атомной энергии добивались на протяжении более чем тридцати лет» (с. 159).

Антиатомное движение в Германии является самой давней, продолжительной, знаменитой формой гражданского протеста в этой стране. Как указывают авторы если, в пятидесятых и шестидесятых годах XX века эти протесты осуществлялись на локальном уровне и проводились отдельными группами граждан, то уже в семидесятые годы несмотря на кризис с энергоносителями (нефтяной конфликт) инициативы антиатомного движения вышли на уровень Земель и Республики в целом. Авторы пишут о массовой демонстрации, в которой участвовало 30000 человек, в 1975 г. занявших стройплощадки и остававшихся на них на протяжении многих месяцев как о крупной акции против строительства АЭС в Виле. Их протест увенчался успехом. Антиатомные протесты имели место и продолжаются не только в связи со строительством или реконструкцией АЭС, но и в связи со строительством и использованием временных или постоянных хранилищ радиоактивных отходов ${ }^{2}$. Эти протесты имеют наиболее сильную базу и опираются на различные социальные группы и поддержку со стороны партий, церкви, экологов, женщин, участников движения за мир, которые как само собой разумеющееся воспринимают участие в антиатомном движении (с. 160). Символ этих

\footnotetext{
${ }^{1}$ Gesetz über die friendliche Verwendung der Kernenergie und den Schutz gegen ihre Gefahren (Atomgesetz) (Закон о мирном использовании атомной энергии и о защите против ее опасностей (Атомный закон) от 15 июня 1985 г.)

${ }^{2}$ См.: Дубовик О.Л., Кремер Л., Люббе-Вольфф Г. Экологическое право. 2-е изд., М.: Эксмо, 2007. - 708 с.
} 
DOI: $10.7256 / 1811-9018.2015 .4 .13329$

При цитировании этой статьи сноска на доі обязательна

\section{Право и политика 4 (184) $\bullet 2015$}

протестов - смеющееся солнце - был везде и остается по прежнему повсюду, подчеркивают авторы книги. Важно также, что целые поколения активистов объединены совместным коллективным опытом. Несмотря на решение о закрытии АЭС в Германии активное движение остается масштабным. В последние годы его участники проводят протесты против использования шахты по добыче соли в Горлебене для захоронения высокорадиоактивных отходов, «Шахты Конрад» в Брауншвайг-ЗалцгиттерВольфенбюттеле, переоборудованной в хранилище радиоактивных отходов и находящейся всего в 20 км от нее «Ассе», бывшей шахты по добыче каменной соли. Более 120000 бочек с радиоактивными жидкими отходами были в них несистематически захоронены, соответственно, с 1967 и 1978 гг. Замеры показывают, что подземные воды проникают в шахты и вступают в контакт с радиоактивными отходами. Поэтому, как показало исследование, участники антиатомных протестов полагают, что принятие 13-го Закона и отказ от использования АЭС не означает прекращение их деятельности.

С. Марг, К. Херманн, В. Хамбауэр, А.Б. Бекс отмечают, что на протяжении десятилетий антиатомное движение создало разветвленную инфраструктуру протеста: многочисленные, находящиеся в контакте и кооперирующиеся группы, систему отработанных мероприятий и инициатив. Их распространенные по всей Германии контакты они характеризуют как «протестмашинерию» (с. 163), регулярные встречи и консультации как «мозговой штурм». Кроме того, участники антиатомного движения использую такие формы как «минимобилизация», «демонстрации ад хок», технические и научные группы профессионалов, а также специальные группы активистов-юристов. Специфической чертой антиатомного движения являются постоянные контакты его участников между собой. Они не ограничиваются подготовкой и проведением акций и протестов как таковых. Участники антиатомного движения часто встречаются в неформальной обстановке - на днях рождения, праздниках и т.п. Высокая степень профессионализма сочетается с возникшим чувством общности что, несомненно, свидетельствует о стабильности и прочности антиатомного движения, укоренившейся мотивации уже третьего поколения участников протестов. В их словаре наличествует своеобразный маркетинг-жаргон и, как отмечают авторы данного раздела книги, «этот язык лежит в основе их рационально-аналитическкой рефлексии, с помощью которой они пытаются вести битву «Давида с Голиафом» одновременно на всех уровнях и как можно эффективнее проводить» (с. 165).
Особо важную роль в антиатомных протестах играют средства массовой информации, с успехом выполняющие роль передатчиков и распространителей взглядов участников протестов. Поэтому общественность широко осведомлена о научных, технических, юридических и иных аспектах борьбы против использования атомной энергии в Германии.

Авторы исследования обращают специальное внимание на политические позиции участников антиатомного движения. Они пишут, что участники антиатомных протестов (как почти никакое другое протестное движение) имеют четкое представление о своих противниках - атомной индустрии, которую они называют «наш враг». Политические взгляды активистов антиатомного движения определяются этой позицией конфронтации, в которой нет нейтрального пространства. В их глазах крупные концерны и производители атомной энергии - лжецы, взяточники, укрыватели информации в целях защиты своих интересов. Скептически относятся они к партиям и политикам. Для антиатомных активистов Фишер (бывший министр иностранных дел), Триттин (бывший министр охраны окружающей среды в правительстве Шредера) и сам Шредер однозначно являются мультипликаторами атомной энергии, поэтому их ожидания от социал-демократов и зеленых не оправдали надежд, а обе партии не сдержали и в самом деле своих предвыборных обещаний относительно отказа от использования атомной энергии и продемонстрировали тем самым зависимость от индустрии (с. 167).

В четвертом разделе анализируются протесты, вызванные реформами в области образования (с.137158), в шестом - системные протесты (с. 178-216), в седьмом - протесты против введения евро (с. 217-247), в восьмом исследуются сатирические протестные группы, а в девятом - Интернет-протесты. В этих частях книги также представлен чрезвычайно интересный материал, но рамки рецензии не позволяют осветить его даже кратким образом, поскольку в этом случае требуются подробные разъяснения сути реформ образования, смысла сатирических протестов и т.п., в то время как экологически ориентированное протестное движение является по своему характеру общим для граждан любой страны.

В заключении, озаглавленном «Гражданственность и протест в обществе недоверия» (С. 299-341) Ф. Вальтер указывает, что участие в протестах требует затрат времени, поэтому активистами часто становятся люди свободных профессий, пенсионеры, учителя, представители иных профессиональных 
DOI: $10.7256 / 1811-9018.2015 .4 .13329$

При цитировании этой статьи сноска на dоі обязательна

Biblion

групп, которые могут более свободно планировать свое рабочее время. Он дает социально-демографическую характеристику опрошенных, приводит данные их о возрасте, социальном статусе, образовании, вероисповедании и т.п. Ф. Вальтер с учетом этих данных делает вывод: гражданские протесты сегодня это действительно протесты граждан, а не маргиналов, деклассированных элементов и тому подобных лиц. Именно поэтому рецензируемая книга носит название «Новая власть граждан».

\section{Библиография:}

1. Дубовик О.Л., Кремер Л., Люббе-Вольфф Г. Экологическое право. 2-е изд., М.: Эксмо, 2007. - 708 с

\section{References (transliterated):}

1. Dubovik O.L., Kremer L., Lyubbe-Vol'ff G. Ekologicheskoe pravo. 2-e izd., M.: Eksmo, 2007. - 708 s 